\title{
The quintessential sustainable resource: cellulose, and the journal named for it
}

\author{
Alfred D. French $\mathbb{1}$
}

Received: 1 January 2019/Accepted: 2 January 2019/Published online: 9 January 2019

(C) Springer Nature B.V. 2019

The United Nations General Assembly has declared 2019 to be the International Year of the Periodic Table of Chemical Elements. By so doing, they are promoting global awareness of how chemistry enables sustainable development and provides solutions to global challenges in energy, agriculture, health, and other critical sectors. The year 2019 is the 150th anniversary of the periodic table and also the 100th anniversary of the International Union of Pure and Applied Chemistry, the world authority on chemical nomenclature, standardized methods for measurement, maintainer of databases, endorser of conferences, and supporter and publisher of scientific research (IUPAC 2017).

In celebration of this special year, SpringerNature, publisher of Cellulose, and other publishers were encouraged to focus on specific elements, or in a more general way, indicate the role of chemistry in sustainable development and solving global challenges, such as with a special issue that would showcase such research in our journal.

Cellulose was first published in 1994, thus these United Nations and IUPAC initiatives fit perfectly with our already-planned 25th Anniversary Special Issue. As our part of the combined celebration,

A. D. French $(\bowtie)$

United States, Department of Agriculture, New Orleans, LA 70124, USA

e-mail: cellulose.editor@gmail.com
Cellulose is pointing out in this Editorial what is obvious to most of its regular readers and authors: as a central science underlying our multidisciplinary efforts, chemistry is providing solutions to global challenges by further developing knowledge of cellulose and other polysaccharides that will underpin future products as well as broadening and strengthening the already vital roles of these sustainable mainstays of our daily lives. Every issue of Cellulose furthers this quest.

Simply put, plants use captured solar energy to convert carbon dioxide and water into cellulose. Estimates vary, but annual production, much of which is wild and not cultivated, is 18 to $70 \times 10^{10}$ billion tons (Puranen et al. 2014). A nearly equal amount decays each year. Forestry, especially eucalyptus, poplar, and pine trees, and cotton farming, are carried out explicitly to obtain the cellulose. In numerous other situations, however, concentrations of highcellulose material arise that are leftovers from processing agricultural materials such as sugarcane bagasse or empty oil palm fruit bunches. They await more profitable exploitation. Furthermore, plants and other organisms produce a panoply of polysaccharides, incredibly diverse in structure, properties, and function. Society makes some use of a few polysaccharides like starch, cellulose, and chitin, but there is vast room for improved utilization of these abundant, 
renewable, benign, and multifunctional materials for global benefit.

Of course, wood is the longest serving cellulosic material. Initially used as a building material and fuel for fires and as simple tools and weapons, paper and regenerated cellulose in the form of rayon fiber became mainstays of an imperfect but, I believe, eventually sufficiently sustainable part of our economy. Research continues to improve these items and their production processes. Other forms of cellulose that take advantage of the small size of the initially biosynthesized units i.e., nanomaterials and bacterial cellulose, are gaining ground. The aerogels and hydrogels that can be made with the nano-sized forms of cellulose are plausible future items that can be used for human tissue replacement scaffolds as well as adsorbents for removing various types of pollutants. Harking back to the use of wood for combustion, modern bioenergy approaches often depend on cellulose in one form or another. Biomedical applications of cellulose and other polysaccharides rely on many beneficial properties including their ability to biodegrade, their frequent compatibility with living systems, and the fact that they can be modified, e.g. to promote therapeutic and targeting purposes.

The need to take full advantage of the ability of plants to convert $\mathrm{CO}_{2}$ to carbohydrate materials has led to a long-term surge in research. New technology such as dynamic nuclear polarization solid state nuclear magnetic resonance and sum frequency generation spectroscopy are enabling new ways to probe the structure of cellulose, allowing for the better development of structure-function relationships. We continue to learn more and more about the biosynthetic processes. Material scientists are continuing to develop new products, while the greening of traditional cellulose-based industries continues.

Because research in recognition of the need for a more sustainable future is increasing, the journal Cellulose is doing well. Since 2008, the journal Cellulose has grown substantially. In that year, we published 87 articles and 825 pages. In 2018, we published 546 articles in 7422 pages! We became, by far, the highest-ranked journal in the Wood Science and Technology sub-category of Life Sciences and Earth Sciences with a Google Scholar h5-index of 53 and an h5-median of 67 (June, 2018). We are proud of the fact that our impact factor has grown to 3.81 (2017). This growth has led to the addition of two new
Associate Editors late this Fall, Professor Ulrica Edlund of the KTH in Sweden, and Associate Professor Nicole (Nikki) R. Brown, Penn State University, USA. They join internationally recognized Professors Kevin Edgar, Virginia Tech, USA; Akira Isogai, University of Tokyo, Japan; and Thomas Heinze, Frederich Schiller University, Germany.

This issue consists of invited papers from some of the leaders of the cellulose and polysaccharide community. There are reviews on some of the technologies that are likely to continue to have important roles in future research as well as some of the exciting cellulose and polysaccharide solvents and product types. On the other hand there are also some traditional research papers that we hope will be of interest.

We express our gratitude to the publisher for their excellent support, and the Editor-in-Chief is grateful to the Associate Editors for their increasing labors. Previous Editor-in-Chief Wolfgang Glasser set the journal on its current course. We depend especially on the reviewers for their advice that has led to many improvements in the journal's content; without them we just could not function. Members of the Editorial Board support the journal in various ways, and, as always, authors are the most important resource.

Brief editorial history of Cellulose

Editors-in-Chief

John C. Roberts

1994-2000

Wolfgang G.

Glasser

2000-2012 (Current Editor

Alfred D. French

Emeritus)

Review Editor:

2013-present

News Editor:

John F. Kennedy 1994-1996

Paul Gatenholm 2000-2006

Associate Editors:

$\begin{array}{ll}\text { R. Malcolm Brown } & \text { 1994-2009 } \\ \text { Derek Gray } & 1994-1999 \\ \text { Fumitaka Horii } & 1994-2009 \\ \text { Bjorn Lindman } & 1994-1999 \\ \text { Dieter Klemm } & 2000-2009 \\ \text { Akira Isogai } & 2010- \\ \text { Thomas Heinze } & 2010- \\ \text { Kevin Edgar } & 2010- \\ \text { Ulrica Edlund } & 2018- \\ \text { Nicole R. Brown } & 2018-\end{array}$


Publishers:

Blackie Academic and Professional: 1994-1998

Kluwer Academic Publishers: 1999-2004

Springer: 2005-

Alfred D. French, Editor-in-Chief

\section{References}

IUPAC (2017) https://theeiupac.wpengine.com/united-nationsproclaims-international-year-periodic-table-chemical-elements/. Accessed 7 Jan 2019

Puranen T, Alapuranen M, Vehmaanperä J (2014) Trichoderma enzymes for textile industries. In: Chen A, Hennessey J, Kenny R, Orbai L (eds) Biotechnology and biology of trichoderma, pp 351-362

Publisher's Note Springer Nature remains neutral with regard to jurisdictional claims in published maps and institutional affiliations. 